\title{
New basal dinosauromorph records from the Dockum Group of Texas, USA
}

\author{
Volkan Sarıgül
}

\begin{abstract}
The basal dinosauromorphs constitute an important component of the Late Triassic Dockum dinosauromorph diversity. This study introduces nine hitherto unpublished hind limb elements of basal dinosauromorphs from Garza and Randall counties in Texas. Most of these specimens consist of femoral and tibial fragments referred to Dromomeron, whereas one complete and one partial fibula resemble the morphology of Marasuchus lilloensis, but with much larger size, and are assigned to undetermined dinosauriforms. The discovery of three Dromomeron specimens in the Tecovas Formation of the Palo Duro Canyon are particularly noteworthy because these are the lowest occurrences of Dromomeron romeri and Dromomeron gregorii, and the first reported biostratigraphic overlap of the two taxa. The extended taxonomic range of $D$. romeri challenges its suggested replacement for $D$. gregorii in the Late Triassic (AdamanianRevueltian) faunal turnover.
\end{abstract}

Volkan Sarıgül. Museum of Texas Tech University, 4th Street, Box 43191, Lubbock, Texas, 79409. volkansaurus@gmail.com

Keywords: Late Triassic; Texas; Dockum; Dinosauromorpha; basal groups; biostratigraphy

Submission: 1 May 2015 Acceptance: 1 June 2016

\section{INTRODUCTION}

The Dinosauromorpha (Benton, 1985) was one of the first clades erected after the introduction of cladistic approach to fossil archosaur studies. Since dinosaurs (including birds) comprise the majority of the dinosauromorphs, the terminology of "non-dinosaurian Dinosauromorpha" or "basal Dinosauromorpha" is useful to cover the close outgroups to the Dinosauria (e.g., Nesbitt et al., 2009; Langer et al., 2013). Early members of this out- group like Lagerpeton chanarensis and Marasuchus lilloensis were discovered in the Chañares Formation (Romer, 1971, 1972), and the basal dinosauromorph fossil record remained restricted to Argentina for the following decades. Larger taxonomic diversity and wider dispersal patterns of these animals during the Mid and Late Triassic were revealed only after new discoveries from the early twenty-first century (e.g., Dzik, 2003; Irmis et al., 2007b; Ferigolo and Langer, 2007; Nesbitt et

Sarıgül, Volkan. 2016. New basal dinosauromorph records from the Dockum Group of Texas, USA. Palaeontologia Electronica 19.2.21A: 1-16

palaeo-electronica.org/content/2016/1498-dockum-basal-dinosauromorphs

Copyright: @ July 2016 Society of Vertebrate Paleontology. This is an open access article distributed under the terms of the Creative Commons Attribution License, which permits unrestricted use, distribution, and reproduction in any medium, provided the original author and source are credited.

creativecommons.org/licenses/by/4.0/ 
al., 2009, 2010; Kammerer et al., 2012; Peecook et al., 2013; Barrett et al., 2015).

Non-dinosaurian dinosauromorphs are also represented in the Upper Triassic terrestrial sediments of the southwestern North America. Technosaurus smalli (Chatterjee, 1984) and Eucoelophysis baldwini (Sullivan and Lucas, 1999) are the two contemporary silesaurids from the Dockum Group and the Chinle Formation, respectively, which were originally considered as dinosaurs (Nesbitt et al., 2007; Irmis et al., 2007a). Probably the most significant contribution to the North American dinosauromorph studies was the discovery of the new basal dinosauromorph taxon Dromomeron (Irmis et al., 2007b). Dromomeron has two species described so far in North America, $D$. romeri and $D$. gregorii, of which the holotypes were, respectively, collected from the Hayden Quarry of the Petrified Forest Member (Chinle Formation) and the Otis Chalk Quarry 3 of the Colorado City Formation (Dockum Group) (Irmis et al., 2007b; Nesbitt et al., 2009). Together with Lagerpeton chanarensis, the two Dromomeron species are grouped in the clade Lagerpetidae, the basal-most dinosauromorph clade (Nesbitt et al., 2009). Various other specimens have been assigned to Dromomeron romeri and to silesaurids coming from the Late Triassic sediments of the Eagle Basin in northwestern Colorado (Small, 2009; Langer et al., 2013).

All of the Dockum non-dinosaurian dinosauromorphs have been collected from the Texas outcrops of the Dockum Group, including the holotype of Technosaurus smalli (Chatterjee, 1984), the holotype of Dromomeron gregorii together with their paratypes and a referred femur (Nesbitt et al., 2009; Martz et al., 2013), and an undetermined dinosauriform tibia that has affinities with silesaurids (Nesbitt and Chatterjee, 2008; Martz et al., 2013). Complementing the previous studies, the description of the unpublished non-dinosaurian dinosauromorph specimens provided here represents the most recent work on the subject.

\section{Geological Setting and Fossil Localities}

Continental sedimentation in the southwestern portion of North America during the Late Triassic was greatly influenced by a huge palaeoriver system named Chinle-Dockum (Riggs et al., 1996), which deposited large volumes of fluvial sediments. Comprising the upstream portion of this ancient river system, the Dockum Group sediments cover vast areas in the western part of Texas and the eastern part of New Mexico (Figure 1). The classical lithostratigraphic framework for the Doc-

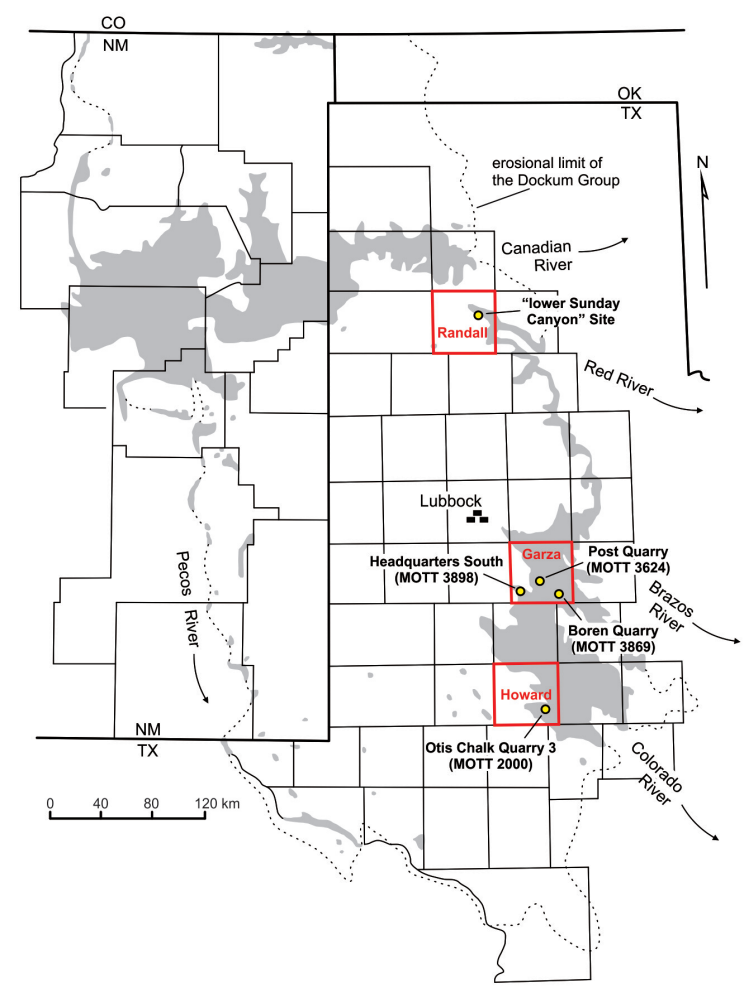

FIGURE 1. The Dockum Group exposures (highlighted in grey) in western Texas and eastern New Mexico (modified after Lehman, 1994a). Fossil localities are spotted (yellow-filled circles) within the corresponding counties of Garza, Howard and Randall (marked in red).

kum Group of Texas is provided by Lehman and Chatterjee (2005). In this scheme, the Dockum fluvial deposition is represented by two sequences: a thinner (less than $80 \mathrm{~m}$ ) older sequence consisting of the Santa Rosa and Tecovas formations and a thicker (over $150 \mathrm{~m}$ ) younger sequence consisting of the Trujillo and Cooper Canyon formations. The two sequences are separated by the "Tr-4" unconformity (Lucas and Anderson, 1993a). In the same work, both sequences are characterized by a fining-upward sequence that starts with basal fluvial channel sandstones (i.e., Santa Rosa and Trujillo formations) and grade into floodplain mudstone and claystone deposits (i.e., Tecovas and Cooper Canyon formations).

Sedimentology and lithostratigraphy of the Dockum Group were recently revisited in southern Garza County (Martz, 2008; Martz et al., 2013). In this work, problems with the lithologic boundaries of the Cooper Canyon Formation were recognized for the first time. Originally coined as the Cooper Member (Chatterjee, 1986), this is a thick mud- 




FIGURE 2. Generalized columnar sections of the Dockum Group in Texas in Randall, Garza and Howard counties, including the stratigraphic positions of the cited quarries in bold (modified after Ash, 1976; Lucas and Anderson, 1993b; Martz, 2008; Martz et al., 2013; and Bill Mueller, personal commun., 2014, 2015). Unit numbers and lithostratigraphic correlatives for the Garza County section are taken from Martz et al. (2013).

stone unit overlying a massive sandstone layer in southeastern Garza County, but the name Cooper was preoccupied by a Tertiary marl unit (Cooke and MacNeil, 1952). As its suggested lithostratigraphic equivalent in the Dockum Group of New Mexico, the name Bull Canyon Formation was proposed as a nomenclatural replacement (Lucas and Hunt, 1989) with priority over the Cooper Canyon Formation, for which a new type section was mea- sured in southern Garza County, as a replacement for the former Cooper Member (Lehman et al., 1992). Accordingly, the Cooper Canyon and Bull Canyon formations were taken as interchangeable, until it was realized that the sandstone layer, the Boren Ranch Sandstone of Frelier (1987), on which the Cooper Member was originally described (Chatterjee, 1986; Lehman et al., 1992) was misidentified as the Trujillo Formation. Therefore, the 

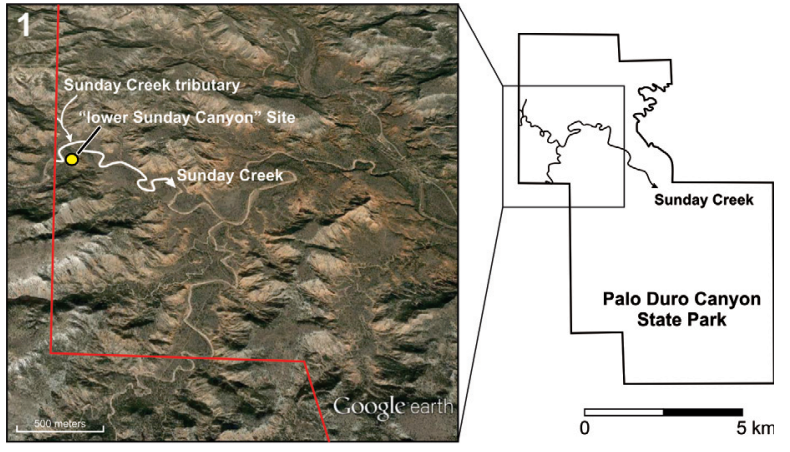

2

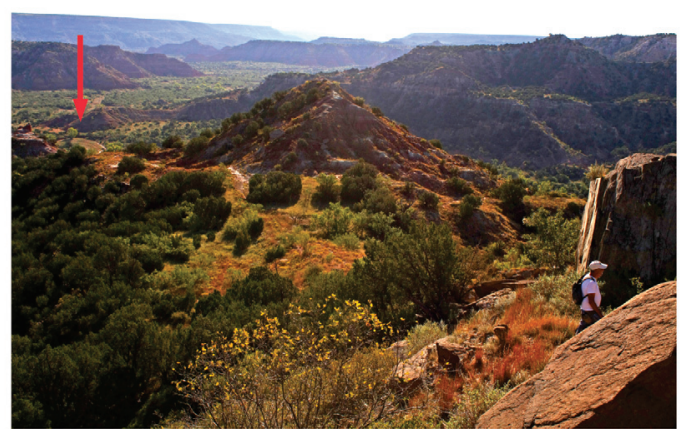

FIGURE 3. 1, Location map of the "lower Sunday Canyon" Site within the Palo Duro Canyon State Park (bordered in red on the map, taken from Google Earth 2016); 2, Field photograph of the "lower Sunday Canyon" Site, indicated by the red arrow (Photo credit: Bill Mueller).

Cooper Canyon Formation sensu Lehman (e.g., Lehman et al., 1992; Lehman, 1994a, 1994b; Lehman and Chatterjee, 2005) covers nearly all the Upper Triassic sediments above the Santa Rosa Formation in southern Garza County and cannot be used as a substitute for the Cooper Member. Martz (2008) employed the name Cooper Canyon Formation for the whole sequence overlying the Boren Ranch Beds, and subdivided it into lower, middle and upper units (Figure 2). Furthermore, it is firmly established that there is no evidence for a "Tr-4" unconformity in the Dockum Group of Texas (Martz, 2008) or in the Chinle Formation of Arizona (Woody, 2006; Parker and Martz, 2011).

In order to provide a fully-established lithostratigraphy, it is needed to reconcile the stratigraphic framework of the Dockum Group in southern Garza County with the rest of the Dockum outcrops in Texas and in New Mexico. Subsequent studies indicated that the lower, middle and upper units of the Cooper Canyon Formation in southern Garza County are equivalent to the Tecovas, Trujillo and Bull Canyon formations, respectively, in northern Garza, Crosby and in other northern Texas counties, and also in New Mexico (e.g., Cather et al.,
2013; Martz et al., 2013) (Figure 2). Lithostratigraphic equivalency of the Dockum Group exposures south to Garza County in Texas is pending and needs more detailed studies; nonetheless, the Colorado City Formation is considered here as a correlate of the lower part of the Tecovas Formation, following the original works of Lucas and Anderson (1993a, 1993b, 1995) (Figure 2).

There are five non-dinosaurian dinosauromorph bearing fossil localities in the Dockum Group of Texas (Figure 1). Boren Quarry (MOTT 3869) and Post Quarry (MOTT 3624) are the two well-known fossil localities from the Garza County that produced a prolific vertebrate assemblage (e.g., Lehman and Chatterjee, 2005; Martz et al., 2013). In the stratigraphic column, they roughly represent the bottom and top levels of the lower unit of the Cooper Canyon Formation, respectively (Figure 2). Technosaurus smalli (TTU-P9021, holotype) is one of the previously published non-dinosaurian dinosauromorph specimens from the Post Quarry, together with a complete left femur of Dromomeron gregorii (TTU-P11282) and a left dinosauriform tibia, which cannot be assigned to a specific taxon (TTU-P11127) (Chatterjee, 1984; Sereno, 1991; Hunt and Lucas, 1994; Irmis et al., 2007a; Nesbitt et al., 2007; Nesbitt and Chatterjee, 2008; Martz et al., 2013). Another fruitful locality from the Garza County is Headquarters South (MOTT 3898) that is placed at the upper part of the middle unit of the Cooper Canyon Formation, a direct correlative of the Trujillo Formation (Figure 2).

The Otis Chalk Quarry 3 (MOTT 2000) and the "lower Sunday Canyon" site are situated in Howard and Randall counties, respectively (Figures 1 and 3). The "lower Sunday Canyon" site (34 $57.530^{\prime} \mathrm{N} 10142.099^{\prime} \mathrm{W}$ ) is located in the eastern end of the Little Fox Canyon within the Palo Duro Canyon State Park where a small tributary joins the Sunday Creek almost due north of the locality (Figure 3). The "lower Sunday Canyon" Site belongs to the lowermost portion of the Tecovas Formation and is placed slightly lower than the Otis Chalk Quarries in the stratigraphic column (Bill Mueller, personal commun., 2015) (Figures 2 and 4). The Otis Chalk quarries include beds from the middle portion of the Colorado City Formation (Lucas and Anderson, 1993b; Lucas et al., 1993) (Figure 2). The holotype of Dromomeron gregorii (TMM 31100-1306) and associated paratypes were collected from the Otis Chalk Quarry 3 (Nesbitt et al., 2009). 


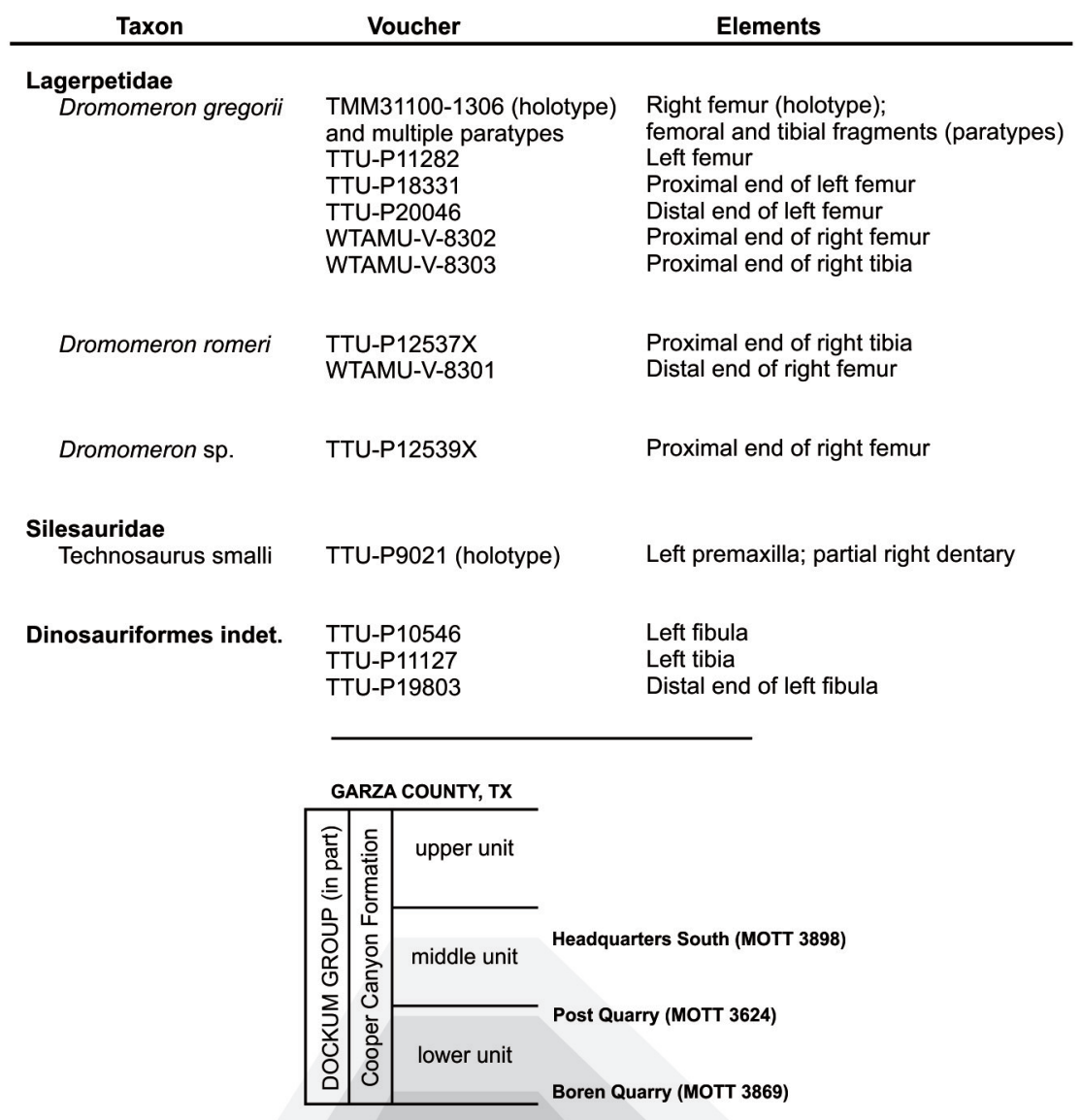

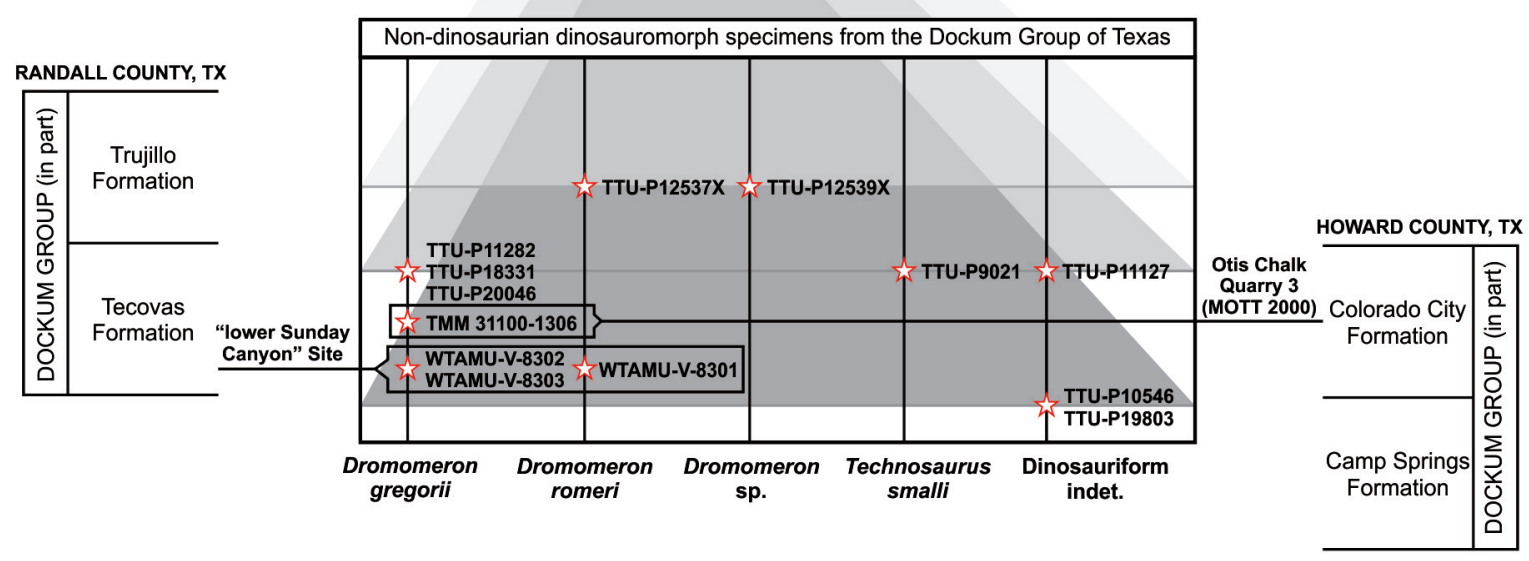

FIGURE 4. Complete listing of hitherto published Dockum non-dinosaurian dinosauromorph specimens from the Dockum Group of Texas with voucher information and representing elements, and their stratigraphic distribution. Lithologic thicknesses are not to scale.

\section{MATERIALS AND METHODS}

Nine basal dinosauromorph specimens are described here. Most of the specimens (TTUP12537X, TTU-P12539X, TTU-P18331, TTUP20046, TTU-P10546 and TTU-P19803) were collected from the southeastern outcrops of the Doc- kum Group of Texas and are reposited in the Museum of Texas Tech University (MoTTU). The dinosauromorph specimens from the Dockum Group of Texas (TTU-P specimens) were collected by Sankar Chatterjee and his crew, especially by Bill Mueller and Doug Cunningham, since the 1980s. The matrix covering the bone surfaces was 

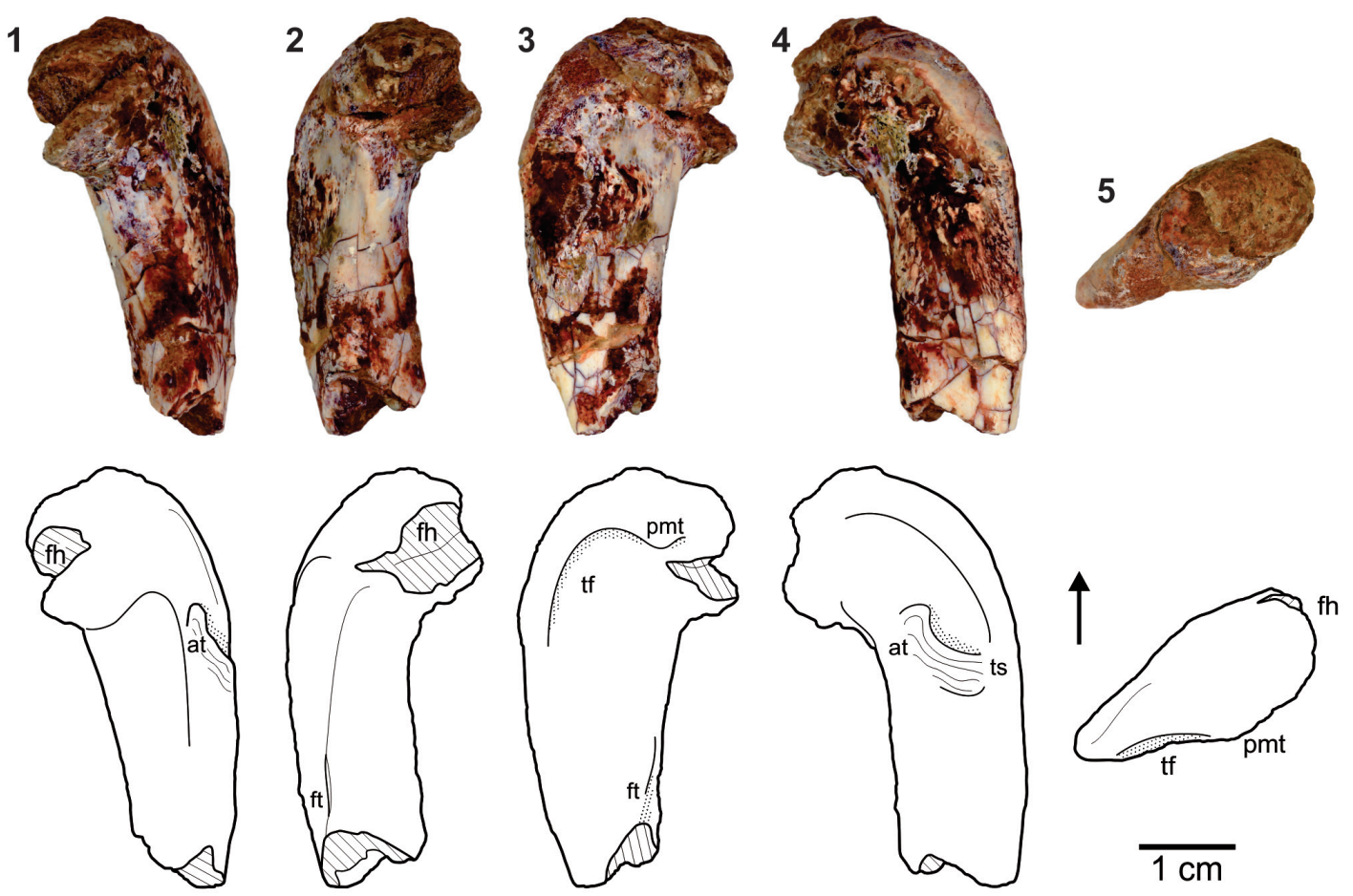

FIGURE 5. Dromomeron gregorii (TTU-P18331), proximal end of left femur in 1, anterior view; 2, medial view; 3, posterior view; 4, lateral view; 5, proximal view. Abbreviations: at, anterior trochanter; fh, femoral head (note that the femoral is broken); ft, fourth trochanter; pmt, posteromedial tuber; tf, trochanteric fossa; ts, trochanteric shelf. Hatching indicates the damaged areas. Arrow indicates anterior side.
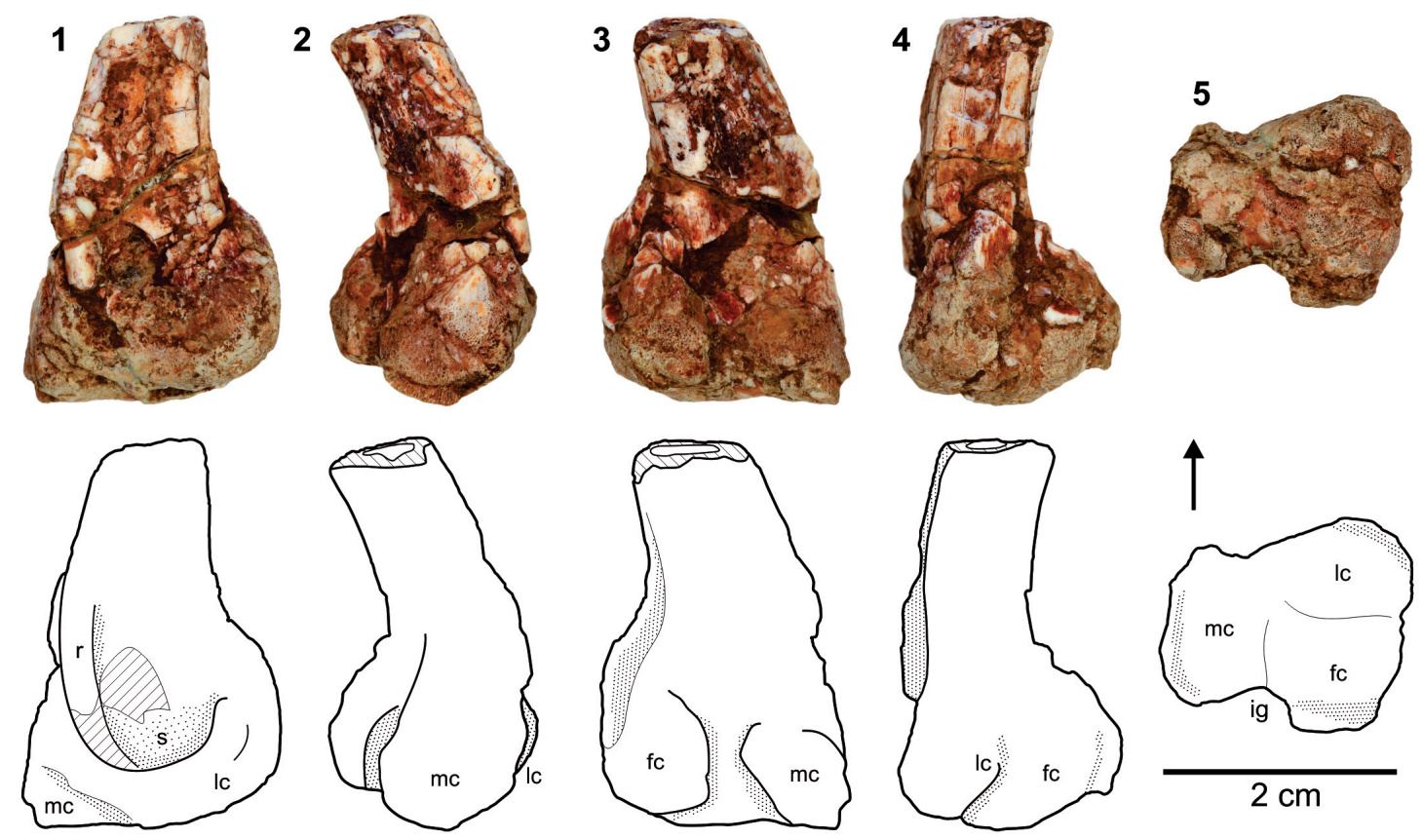

FIGURE 6. Dromomeron gregorii (TTU-P20046), distal end of left femur in 1, anterior view; 2, medial view; 3 , posterior view; 4, lateral view; 5, distal view. Abbreviations: fc, fibular condyle; ig, intercondylar groove; lc, lateral condyle; $\mathbf{m c}$, medial condyle; $\mathbf{r}$, ridge; s, scar. Hatching indicates the damaged areas. Arrow indicates anterior side. 

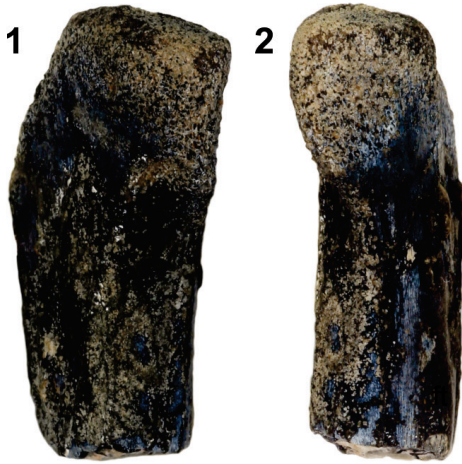

3
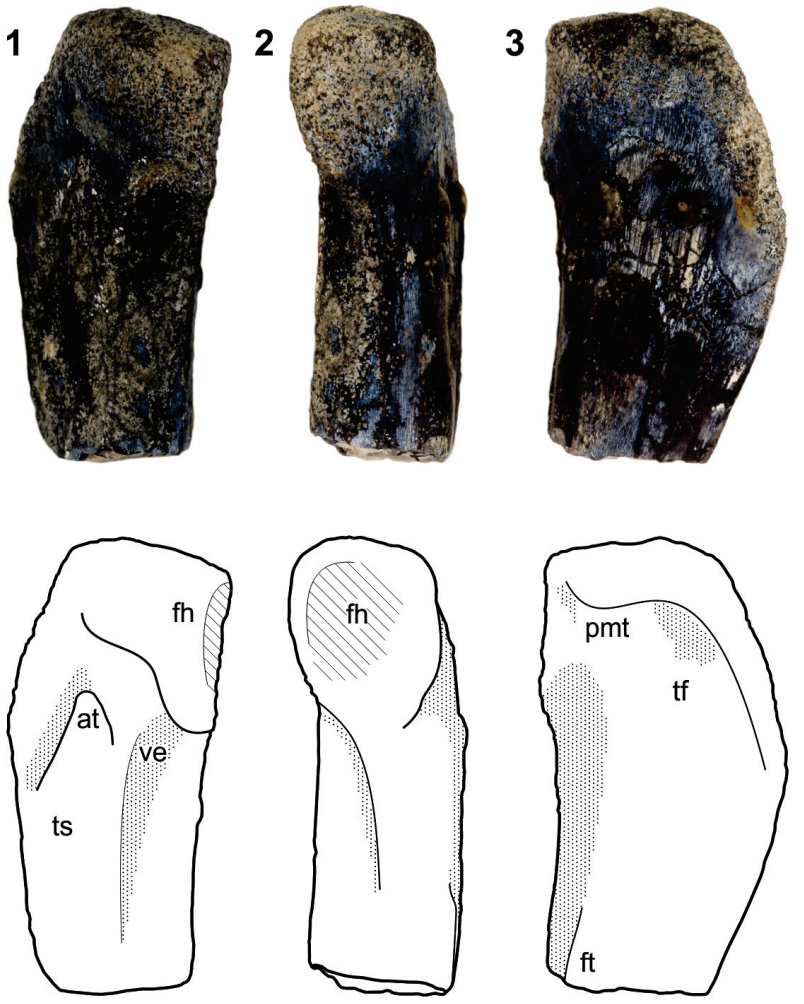
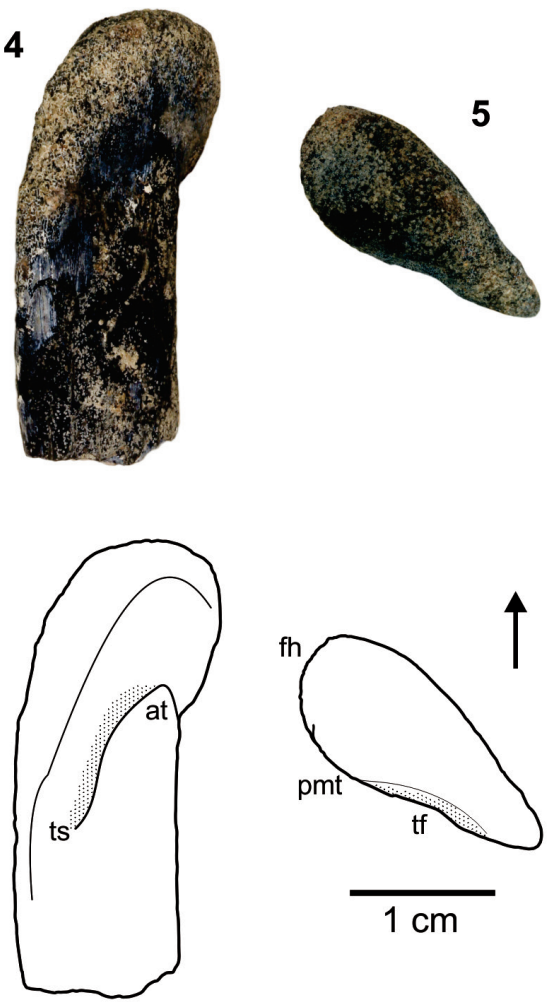

FIGURE 7. Dromomeron gregorii (WTAMU-V-8302), proximal end of right femur in 1, anterior view; 2, medial view; 3 , posterior view; 4, lateral view; 5, proximal view. Abbreviations: at, anterior trochanter; fh, femoral head; ft, fourth trochanter; pmt, posteromedial tuber; tf, trochanteric fossa; ts, trochanteric shelf; ve, ventral emargination. Hatching indicates the damaged areas. Arrow indicates anterior side.

removed mechanically in the MoTTU fossil preparation lab, and photographs were taken by a professional photographer (Bill Mueller). Three additional specimens (WTAMU-V-8301, WTAMU$\mathrm{V}-8302$ and WTAMU-V-8303) were loaned from West Texas A\&M University (WTAMU). These three specimens were recovered from a prepared pile of assorted bone fragments collected from the same stratigraphic horizon by Gerald E. Schultz from Palo Duro Canyon State Park (i.e., the "lower Sunday Canyon" Site). The corresponding information about the collection site and catalog numbers for these specimens were also obtained from G.E. Schultz. The preliminary data for all the TTU-P and WTAMU specimens were included in an unpublished dissertation (Sarıgül, 2014), whereas the voucher information for type specimens of Dromomeron gregorii collected from the Otis Chalk Quarry 3 (MOTT 2000) refers to the original publication of Sterling Nesbitt and his colleagues (2009).

\section{SYSTEMATIC PALAEONTOLOGY}

ARCHOSAURIA Cope 1869 sensu Gauthier, 1986 DINOSAUROMORPHA Benton, 1985

LAGERPETIDAE Arcucci 1986 sensu Nesbitt et al., 2009

Dromomeron gregorii Nesbitt et al., 2009

Figures 4-8

Material. Proximal end of left femur (TTU-P18331) and distal end of left femur (TTU-P20046) from the Post Quarry (MOTT 3624); proximal end of right femur (WTAMU-V-8302) and proximal end of right tibia (WTAMU-V-8303) from the "lower Sunday Canyon" Site (Figure 4).

Description and remarks. Although the damaged tip of the femoral head obliterates the anteromedial tuber, the posteromedial tuber of TTU-P18331 is well preserved (Figure 5). The trochanteric fossa is situated posteriorly. The anterior trochanter with a trochanteric shelf is distinct as a rugose ridge on the anterolateral side. The fourth trochanter bulges out more distally on the posteroventral side. The enlarged posteromedial tuber is the most conspicuous lagerpetid character of TTU-P18331, and this 

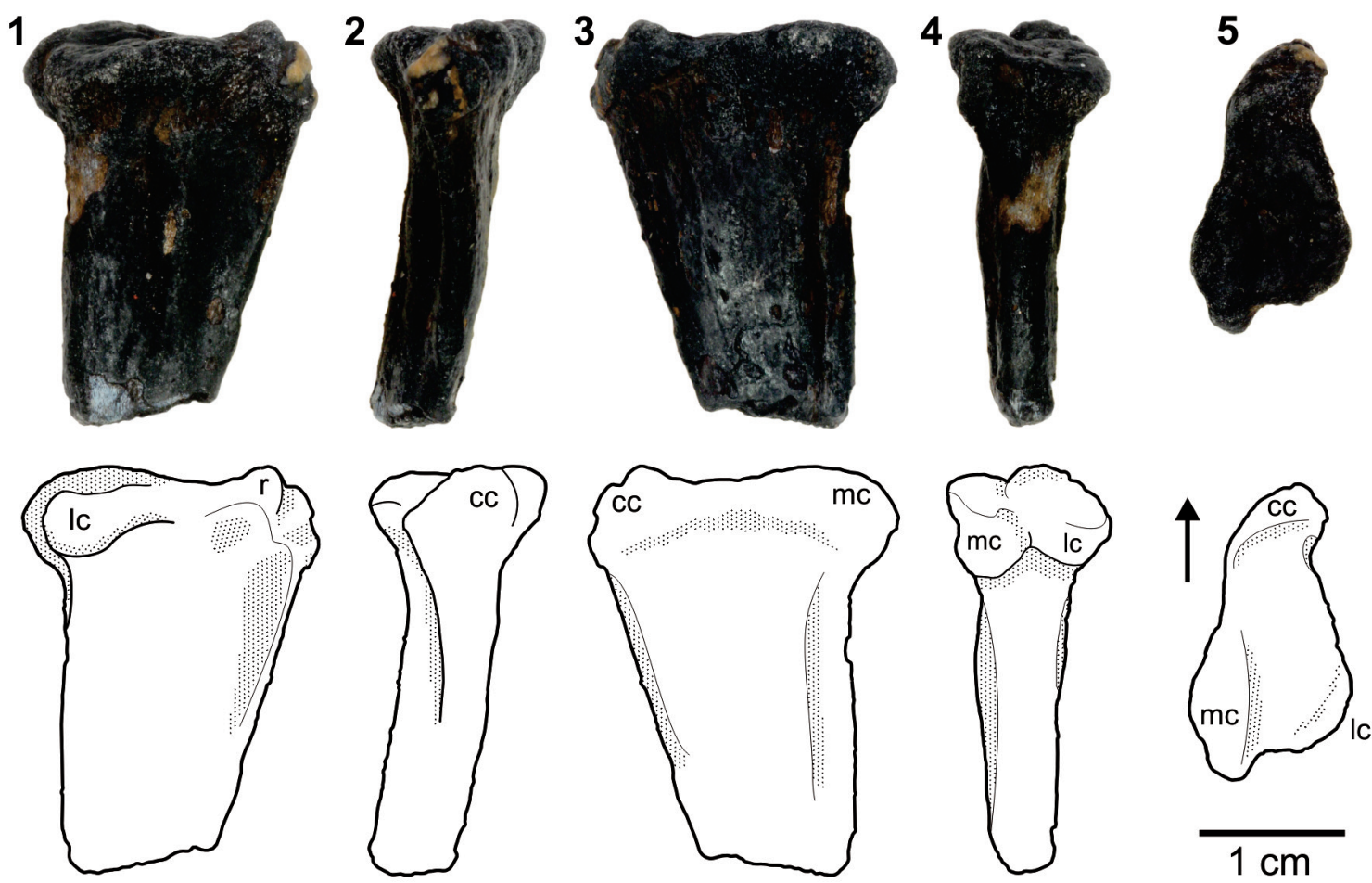

FIGURE 8. Dromomeron gregorii (WTAMU-V-8303), proximal end of right tibia in 1, lateral view; 2, anterior view; 3, medial view; 4, posterior view; 5, proximal view. Abbreviations: cc, cnemial crest; lc, lateral crest; mc, medial crest; $\mathbf{r}$, ridge. Arrow indicates anterior side.

specimen can be assigned to $D$. gregorii based on the presences of an anterior trochanter with a trochanteric shelf and a fourth trochanter.

As in TTU-P11282 (Martz et al., 2013) and in all the specimens referred to Dromomeron (Nesbitt et al., 2009), the muscle scar for the M. femorotibialis externus is expressed as a rounded fossa that is slightly damaged in TTU-P20046 (Figure 6). The distal condyles are substantially enlarged compared to $D$. romeri, and the characteristic intercondylar groove between the medial and the fibular condyles is also highly reduced due to the relative enlargement of the latter.

Despite the fact that the anteromedial tuber of the femoral head is obliterated, the enlarged posteromedial tuber is quite distinct on WTAMU-V8302, which represents an unequivocal lagerpetid character together with the ventral emargination located on the anteromedial side (Figure 7). As an expansion of the anterior trochanter, the trochanteric shelf provides a prominent and rugose muscle attachment surface. Only the proximal part of the fourth trochanter is preserved. An anterior trochanter with a trochanteric shelf and a fourth trochanter are typical traits of $D$. gregorii to which WTAMU-V8302 is assigned.
The proximal surface of WTAMU-V-8303 is triangular and significantly longer in the anteroposterior direction (Figure 8). The cnemial crest is prominent with a small ridge on its tip, which is slightly projected laterally. A small lateral depression that stands posterior to the cnemial crest does not produce a strict sense tibial notch, since it does not extend down along the shaft. The lateral condyle is ventrally deflected and smaller than the medial, which is expanded posteriorly with a tapering tip, as in $D$. gregorii. The preserved portion of the shaft is mediolaterally compressed.

\section{Dromomeron romeri Irmis et al. 2007b}

Figures 4, 9-10

Material. Proximal end of right tibia (TTU$P 12537 X)$ from the Headquarters South locality (MOTT 3898); distal end of right femur (WTAMU-V8301) from the "lower Sunday Canyon" Site (Figure 4).

Description and remarks. The proximal surface of TTU-P12537X is triangular and the three sides are almost equal in length (Figure 9). The cnemial crest is small but distinct, and its tip is slightly projected laterally. Posterior condyles are aligned, not pronounced and separated by a very shallow cleft. 

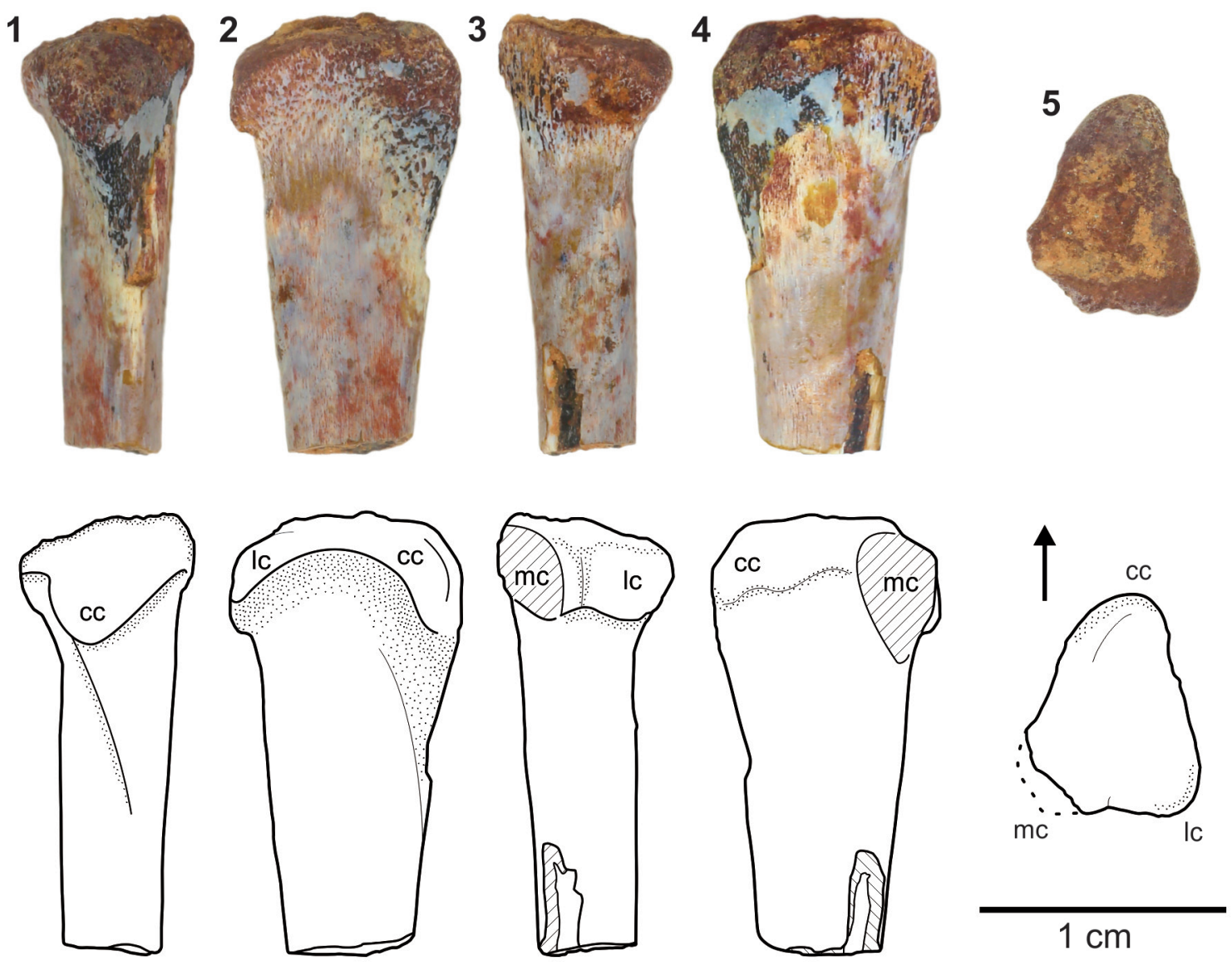

FIGURE 9. Dromomeron romeri (TTU-P12537X), proximal end of right tibia in 1, anterior view; 2, lateral view; 3, posterior view; 4, medial view; 5, proximal view. Abbreviations: cc, cnemial crest; lc, lateral condyle; mc, medial condyle. Hatching indicates the damaged areas. Arrow indicates anterior side.

The lateral condyle is ventrally deflected, as diagnostic of Dromomeron (Nesbitt et al., 2009). Even though the medial condyle is obliterated, the posterior condyles seem to be aligned and sub-equal in size, a character that is more comparable to $D$. romeri (see Irmis et al., 2007b, figure 2; Nesbitt et al., 2009, figure 4).

The slender shaft of WTAMU-V-8301 significantly widens distally with a distinct ridge on the anteromedial side that establishes its affinity to Dromomeron romeri (Irmis et al., 2007b) (Figure 10). The distal end is much larger mediolaterally than anteroposteriorly. Condyles are small and gracile as noted for $D$. romeri (Nesbitt et al., 2009). Medial and fibular condyles are well separated by the intercondylar groove.

\section{Dromomeron sp.}

Figures 4, 11

Material. Proximal end of right femur (TTUP12539X) from the Headquarters South locality (MOTT 3898) (Figure 4).
Description and remarks. The head (or capitulum) of the proximal femur is broken but its hooked morphology of a typical lagerpetid is still traceable (Figure 11). The posteromedial tuber and adjacent trochanteric fossa (facies articularis antitrochanterica) are distinct. Right below the broken capitulum, a very faint emargination is present on the anterolateral side. The femoral shaft bears no anterior trochanter or a trochanteric shelf; the absence of which was previously noted for $D$. romeri and also for the smaller specimens of $D$. gregorii. Unfortunately, the inadequate preservation prevents a species-level assignment for this specimen.

\section{DINOSAUROMORPHA Benton, 1985 \\ DINOSAURIFORMES Novas, 1992}

Gen et sp. indet.

Figures 4, 12-13

Material. Left fibula (TTU-P10546) and distal end of left fibula (TTU-P19803) from the Boren Quarry (MOTT 3869) (Figure 4). 

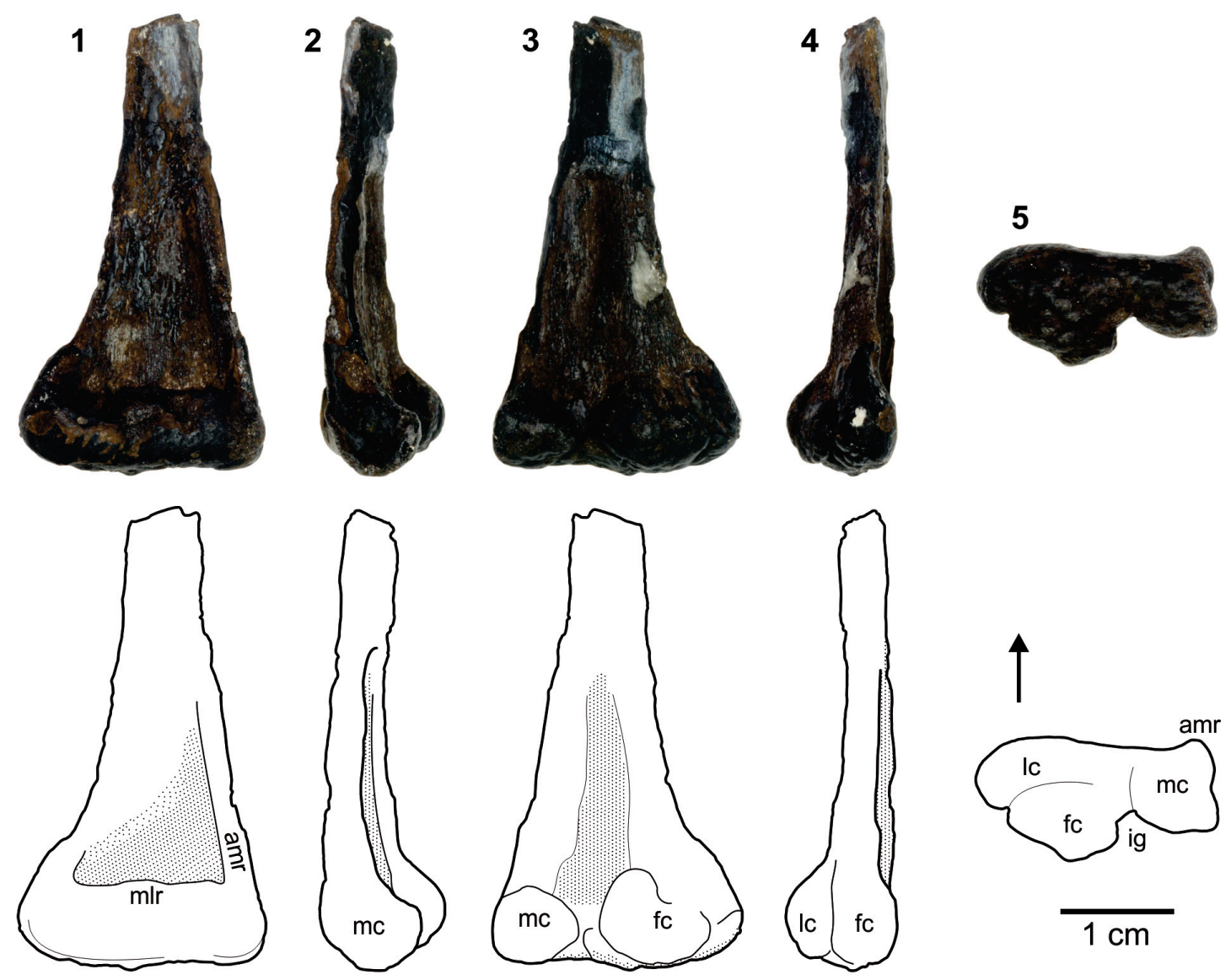

FIGURE 10. Dromomeron romeri (WTAMU-V-8301), distal end of right femur in 1, anterior view; 2, medial view; 3, posterior view; 4, lateral view; 5, distal view. Abbreviations: amr, anteromedial ridge (sensu Irmis et al., 2007b); fc, fibular condyle; ig, intercondylar groove; Ic, lateral condyle; mc, medial condyle; mlr, mediolateral ridge. Arrow indicates anterior side.

Description and remarks. TTU-P10546 represents a complete and mediolaterally compressed left fibula (Figure 12). The proximal articulation is elongated in the anteroposterior direction and slightly altered around the edges. The anterior end of the proximal portion tapers smoothly with the missing tip and slightly curved anteromedially. The lateral corner of the posterior end is projected posterolaterally. The shaft is straight, slender, transversely compressed and considerably damaged where the attachment site for the M. iliofibularis was to be detected. The anterior and lateral borders of the distal end are rounded, whereas the posterior corner is expanded posteroventrally and becomes a prominent process. The reflection of this process on the distal surface is a small pyramidal tuberosity. There are two attachment surfaces detected on the distal surface. The lateral attachment surface is concave, extending from the posterior side towards the slightly raised medial side. This helical morphology of the lateral attachment surface probably conforms to the unevenly raised articular facet formed by astragalus and calcaneum. The medial attachment surface is located on the posteromedial side of the distal surface and bears a slight bevel expressed on the anteromedial portion. This is visible in both medial and distal views, probably articulating with the lateral edge of the ascending process of the astragalus.

The proximal end and shaft of TTU-P10546 have the typical plesiomorphic dinosauromorph morphology (e.g., Langer, 2004; Nesbitt, 2011), and the main indicative of its affinity is probably the configuration of the distal end, which differs substantially from the lagerpetid and dinosaurian condition. The lagerpetid distal part of fibula is documented only in Lagerpeton chanarensis (Sereno and Arcucci, 1993), where both anterior and posterior ends of the convex distal articular surface are elongated and tapering over the tibia and astragalus, respectively. In Silesaurus opolensis and in basal saurischians, on the other hand, 

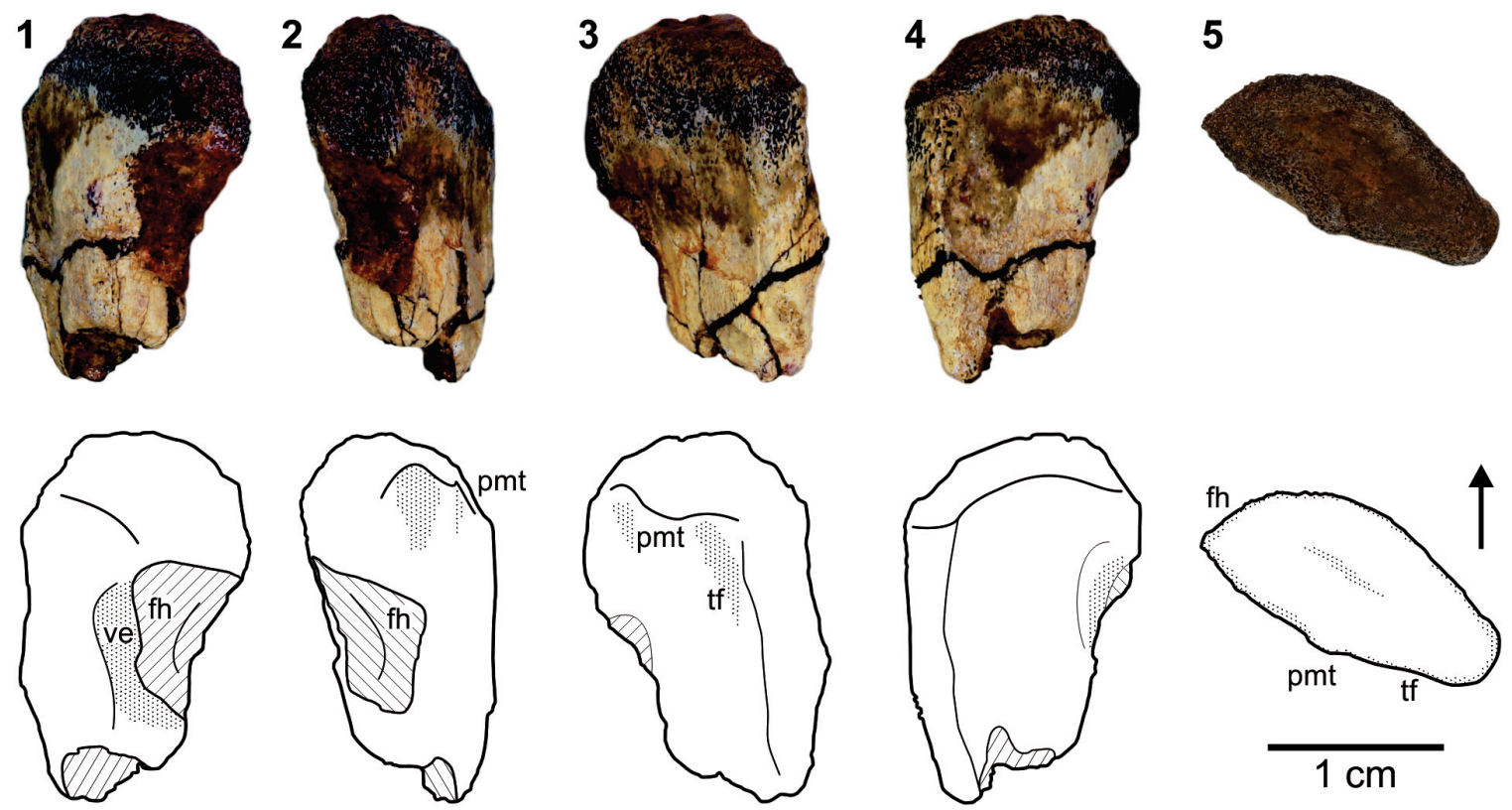

FIGURE 11. Dromomeron sp. (TTU-P12539X), proximal end of right femur in 1, anterior view; 2, medial view; 3, posterior view; 4, lateral view; 5, proximal view. Abbreviations: fh, femoral head (note that the femoral head is broken); pmt, posteromedial tuber; tf, trochanteric fossa; ve, ventral emargination. Hatching indicates the damaged areas. Arrow indicates anterior side.

the distal surface of the fibula is flattened, and it is widened in anteroposterior (or anteromedial-posterolateral) axis with a distinct posterior tuber (e.g., Novas, 1993; Bonaparte et al., 1999; Langer, 2003; Dzik, 2003, figure 13C; Sereno et al., 2013). The basal ornithischian condition is even more peculiar; the fibula is reduced to a rod, where the distal portion is significantly twisted and fused to the tibia and astragalocalcaneum (e.g., Butler, 2005; Butler et al., 2010; Norman et al., 2011). Pisanosaurus mertii somewhat differs from the typical ornithischian condition by lacking the distal torsion and yielding an expanded distal end (Bonaparte, 1976; Norman et al., 2004).

The distal portion of the fibula of Marasuchus lilloensis offers the best comparison for TTUP10546. Following the original description of Sereno and Arcucci (1994), the distal portion of the M. lilloensis fibula possesses an elliptical distal surface that is anteroposteriorly concave but mediolaterally convex with a distinct bevel on the medial side. A prominent tuber is present on the posterior corner, as described for TTU-P10546. In both taxa, the enlargement of the posterior tuberosity forms an asymmetrical distal end uniquely among ornithodirans (Nesbitt, 2011, character 345), differing from the posterodistal inclination on the flattened lateral border of the distal fibula seen in some basal saurischians like Eoraptor lunensis and Herrerasaurus ischigualastenesis (Novas, 1993; Sereno et al., 2013). However, the medial edge is more rounded and the subdivision of the articular facets, if present, is less conspicuous in the distal part of the M. lilloensis fibula (Sereno and Arcucci, 1994, figure 12A). There is also a notable size difference between the two fibulae; the maximum length of the $M$. lilloensis fibula is about $7 \mathrm{~cm}$ (Sereno and Arcucci, 1994, table 5), whereas TTU$\mathrm{P} 10546$ is more than three times longer $(24 \mathrm{~cm})$.

Since only the distal end of TTU-P19803 is preserved, the overall morphology and size is similar to those of TTU-P10546; only slightly more compressed mediolaterally (Figure 13). The lateral and anterior borders are rounded; a prominent process occurs on the posterior side that is followed by a small pyramidal tuberosity on the distal surface. The lateral and medial articulation surfaces seen in TTU-P10546 are not discernable in TTUP19803; the tarsal articulation surfaces are represented by a single concave surface that is raised towards the medial side. This pattern is more compatible to that observed for $M$. lilloensis (Sereno and Arcucci, 1994, figure 12A). 

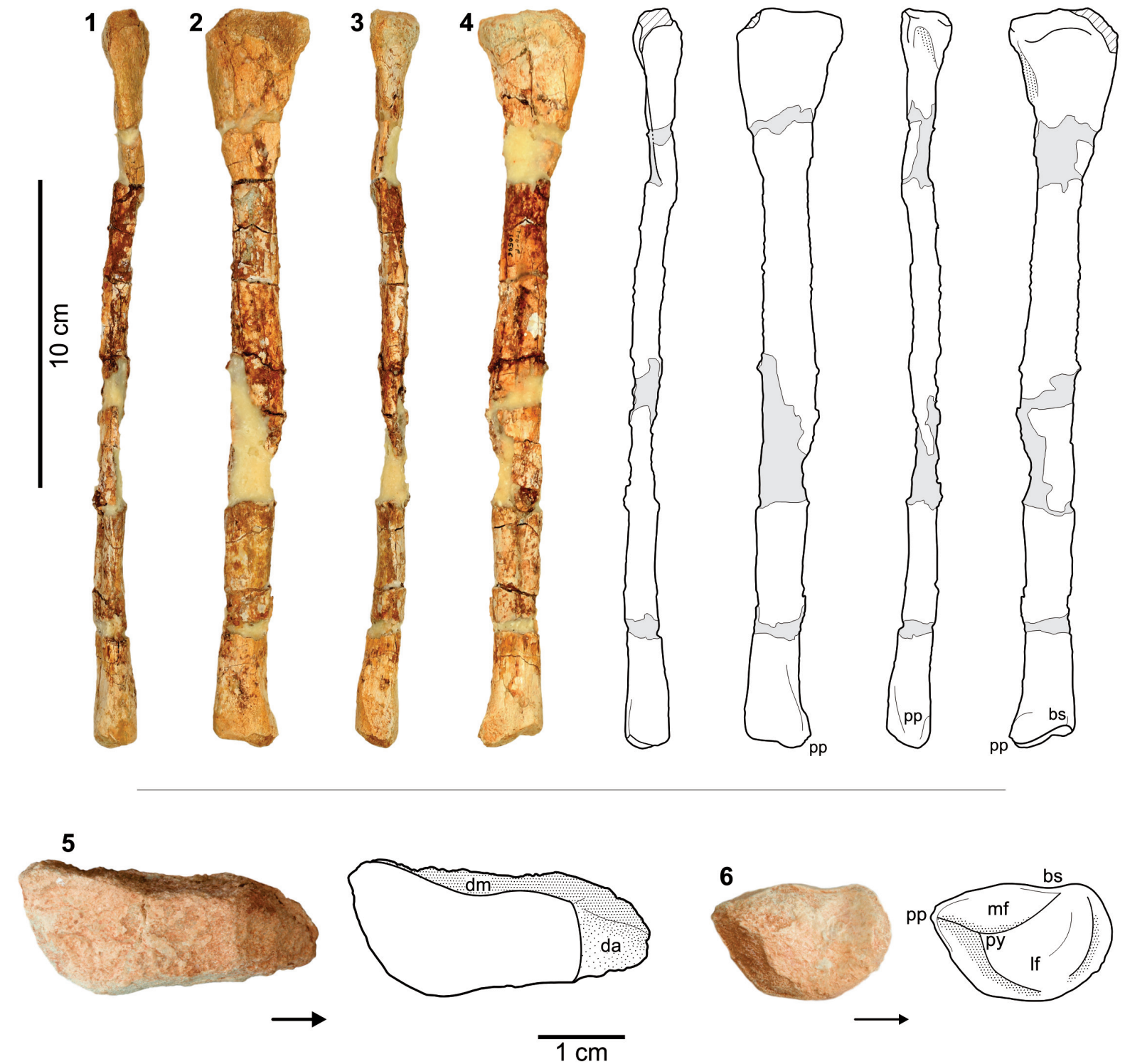

FIGURE 12. Dinosauriformes gen. and sp. indet. (TTU-P10546), left fibula in 1, anterior view; 2, lateral view; 3, posterior view; 4, medial view; 5, proximal view; 6, distal view. Abbreviations: bs, beveled surface; da, damaged anterior part; dm, damaged posterior part; If, lateral facet; mf, medial facet; pp, posterior process; py, pyramidal process. Arrow indicates anterior side.

\section{CONCLUSION AND DISCUSSIONS}

The dinosauromorph record of the Dockum Formation is important for understanding the distribution of ornithodirans in southern North America. Basal dinosauromorph specimens are presently unknown from the Dockum Group of New Mexico, leaving the Texas specimens as the only current record. Previously published specimens include the type specimens of Dromomeron gregorii (TMM 31100-1306 and associated paratypes), a left femur referred to $D$. gregorii (TTU-P11282), the holotype of the silesaurid Technosaurus smalli (TTU-P9021), and an isolated tibia possibly attributable to a silesaurid (TTU-P11127). The new nondinosaurian dinosauromorph specimens described here are referred to Dromomeron romeri (TTUP1253X7; WTAMU-V-8301), Dromomeron gregorii (TTU-P18331; TTU-P20046; WTAMU-V-8302; WTAMU-V-8303) and Dromomeron sp. (TTU$P 12539 X$ ), with two remaining specimens (TTUP10546; TTU-P19803) assigned to Dinosauriformes indet. based on their morphologic similarities to the fibula of Marasuchus lilloensis, 

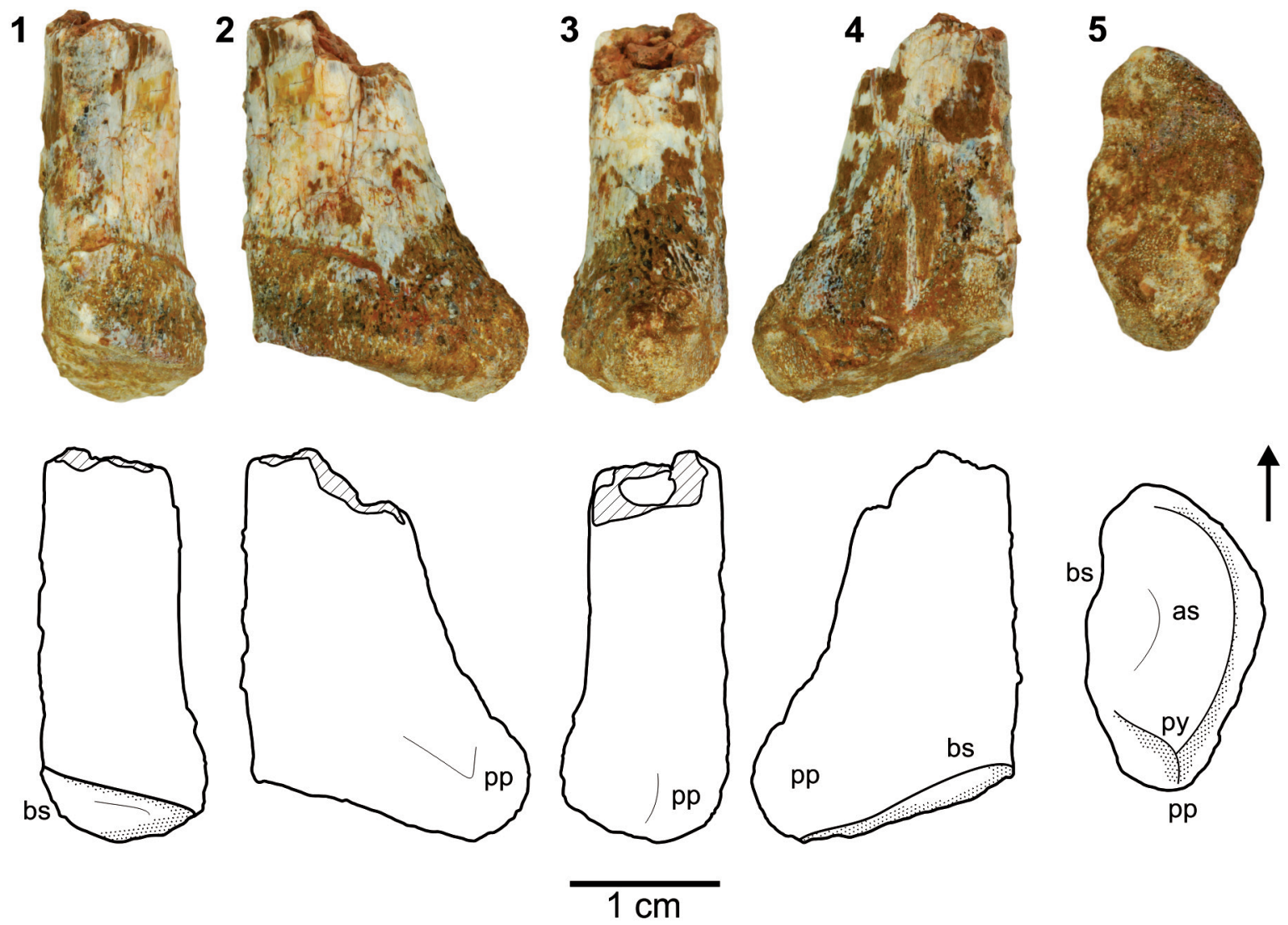

FIGURE 13. Dinosauriformes gen. and sp. indet. (TTU-P19803), distal end of left fibula in 1, anterior view; 2, lateral view; 3, posterior view; 4, medial view; 5, distal view. Abbreviations: as, articular surface for astragalus and calcaneum; bs, beveled surface; pp, posterior process; py, pyramidal process. Hatching indicates the damaged areas. Arrow indicates anterior side.

regardless of their different sizes (Figures 4-13). Despite the fragmentary nature of the specimens, it can be concluded that the Late Triassic non-dinosaurian dinosauromorph fauna of the Dockum Group was taxonomically diverse.

The stratigraphic distribution of the Dromomeron specimens also deserves special attention. Previously, the fossil record of $D$. romeri was restricted to the upper levels of the Chinle Formation (i.e., the Petrified Forest Member), whereas $D$. gregorii was collected from the lower levels of both Dockum and Chinle sequences. Since the Dockum Group and the Chinle Formation are coeval and lithostratigraphically equivalent (e.g., Cather et al., 2013), it has been questioned whether there is a possible temporal succession of the two species (Nesbitt et al., 2009). The Dromomeron fossil record in the Dockum Group of Texas supports this theory. In Garza County, specimens of D. romeri are collected from the middle unit of the Cooper Canyon Formation (TTU-P12537X), whereas D. gregorii fossils are recorded only in the lower unit of the Cooper Canyon Formation (TTU-P18331; TTU-P20046) (Figures 2 and 4). Similarly, the Otis Chalk Quarry 3 (MOTT 2000) where the Dromomeron gregorii was discovered is located in a relatively low stratigraphic position within the Dockum Group (Figures 2 and 4). However, the discovery of specimens WTAMU-V-8301, WTAMU-V8302 and WTAMU-V-8303 from the same stratigraphic horizon of the "lower Sunday Canyon" Site demonstrates the ranges of the two Dromomeron species overlap (Figure 4). These findings not only document the first co-occurrence of $D$. romeri and $D$. gregorii, but also represent the lowest occurrences of both Dromomeron species in North America. Moreover, WTAMU-V-8301 extends the taxon range of $D$. romeri down to the lower levels of the Tecovas Formation, a situation implying that $D$. romeri existed during most of the Late Triassic. Concurrently, the suggested replacement of $D$. gregorii by $D$. romeri at the Adamanian-Revueltian 
faunal transition (Parker and Martz, 2011) seems to reflect a sampling bias.

Now, the extension of the $D$. gregorii range gains importance to test the possible extinction of this taxon at the Adamanian-Revueltian boundary. The Post Quarry (MOTT 3624) and the Placerias Quarry of the Sonsela Member (Ramezani et al., 2014) are the two uppermost quarries from the Dockum Group and the Chinle Formation from where $D$. gregorii fossils were obtained (Nesbitt et al., 2009; Martz et al., 2013). Any future discovery of $D$. gregorii from the overlying sequences will show that this taxon was not affected by this Late Triassic faunal turnover, just like $D$. romeri. Therefore, Dromomeron taxon ranges should be refined with additional sampling in the future to further support these faunal turnover inferences.

\section{ACKNOWLEDGEMENTS}

The author owes special thanks to S. Chatterjee for providing the material and workspace, to G.E. Schultz and B. Mueller for sharing their personal data and observations, and to the Museum of Texas Tech University staff for their friendly attitude.

\section{REFERENCES}

Arcucci, A.B. 1986. Nuevos materiales y reinterpretacion de Lagerpeton chanarensis Romer (Thecodontia, Lagerpetonidae nov.) del Triassic Medio de La Rioja, Argentina. Ameghiniana, 23:233-242.

Ash, S.R. 1976. Occurrence of the controversial plant fossil Sanmiguelia in the Upper Triassic of Texas. Journal of Paleontology, 50:799-804.

Barrett, P.M., Nesbitt, S.J., and Peecook, B.R. 2015. A large-bodied silesaurid from the Lifua Member of the Manda Beds (Middle Triassic) of Tanzania and its implications for body-size evolution in Dinosauromorpha. Gondwana Research, 27:925-931.

Benton, M.J. 1985. Classification and phylogeny of the diapsid reptiles. Zoological Journal of the Linnean Society, 84:97-164.

Bonaparte, J.F. 1976. Pisanosaurus mertii Casamiquela and the origin of the Ornithischia. Journal of Paleontology, 50:808-820.

Bonaparte, J.F., Ferigolo, J., and Riberio, A.M. 1999. A new early Late Triassic saurischian dinosaur from Rio Grande do Sul state, Brazil, p. 89-109. In Tomida, Y., Rich, T.H., and Vickers-Rich, P. (eds.), Proceedings of the Second Gondwanan Dinosaur Symposium. National Science Museum Monographs no.15, Tokyo.

Butler, R.J. 2005. The 'fabrosaurid' ornithischian dinosaurs of the Upper Elliot Formation (Lower Jurassic) of South Africa and Lesotho. Zoological Journal of the Linnean Society, 145:175-218.

Butler, R.J., Porro, L.B., Galton, P.M., and Chiappe, L.M. 2010. Anatomy and cranial functional morphology of the small-bodied dinosaur Fruitadens haagarorum from the Upper Jurassic of the USA. PLOS ONE, 7:e31556. doi:10.1371/journal.pone.0031556.

Cather, S.M., Zeigler, K.E., Mack, G.H., and Kelley, S.A. 2013. Towards standardization of Phanerozoic stratigraphic nomenclature in New Mexico. Rocky Mountain Geology, 48:101-124.

Chatterjee, S. 1984. A new ornithischian dinosaur from the Triassic of North America. Naturwissenschaften, 71:630-631.

Chatterjee, S. 1986. The Late Triassic Dockum vertebrates: their stratigraphic and paleobiogeographic significance, p. 139-150. In Padian, K. (ed.), The Beginning of the Age of Dinosaurs: Faunal Change Across the Triassic-Jurassic Boundary. Cambridge University Press, Cambridge.

Cooke, C.W. and MacNeill, F.S. 1952. Tertiary Stratigraphy of South Carolina. U.S. Geological Survey Professional Paper, 243:19-29.

Cope, E.D. 1869. Synopsis of the extinct Batrachia and Reptilia of North America, Part I. Transactions of the American Philosophical Society, 14:1-252.

Dzik, J. 2003. A beaked herbivorous archosaur with dinosaur affinities from the early Late Triassic of Poland. Journal of Vertebrate Paleontology, 23:556574.

Ferigolo, J. and Langer, M.C. 2007. A Late Triassic dinosauriform from south Brazil and the origin of the ornithischian predentary bone. Historical Biology, 19:1-11.

Frelier, A.P. 1987. Sedimentology, fluvial paleohydrology, and paleogeomorphology of the Dockum Formation (Triassic), west Texas. Unpublished M.Sc. thesis, Texas Tech University, Lubbock, Texas, USA.

Gauthier, J.A. 1986. Saurischian monophyly and the origin of birds. Memoirs of California Academy of Sciences, 8:1-55.

Google Earth 2016. "Palo Duro Canyon State Park, in part" Map. Google, retrieved in 12 February 2016.

Hunt, A.P. and Lucas, S.G. 1994. Ornithischian dinosaurs from the Upper Triassic of the United States, $p$. 227-241. In Fraser, N.C. and Sues, H.-D. (eds.), In the Shadow of the Dinosaurs: Early Mesozoic Tetrapods. Cambridge University Press, Cambridge.

Irmis, R.B., Parker, W.G., Nesbitt, S.J., and Liu, J. 2007a. Early ornithischian dinosaurs: the Triassic record. Historical Biology, 19:3-22.

Irmis, R.B., Nesbitt, S.J., Padian, K., Smith, N.D., Turner, A.H., Woody, D., and Downs, A. 2007b. A Late Triassic dinosauromorph assemblage from New Mexico and the rise of dinosaurs. Science, 317:358-361.

Kammerer, C.F., Nesbitt, S.J., and Shubin, N.H. 2012. The first silesaurid dinosauriform from the Late Triassic of Morocco. Acta Palaeontologica Polonica, 57:277-284. 
Langer, M.C. 2003. The pelvic and hind limb anatomy of the stem-sauropodomorph Saturnalia tupiniquim (Late Triassic, Brazil). PaleoBios, 23:1-30.

Langer, M.C. 2004. Basal Saurischia, p. 24-46. In Weishampel, D.B., Dodson, P., and Osmólska, H. (eds.), The Dinosauria, second edition. University of California Press, Berkeley.

Langer, M.C., Nesbitt, S.J., Bittencourt, J.S., and Irmis, R.B. 2013. Non-dinosaurian Dinosauromorpha, p. 157-187. In Nesbitt, S.J., Desojo, J.B. and Irmis, R.B. (eds.), Anatomy, Phylogeny and Palaeobiology of Early Archosaurs and Their Kin, Geological Society Special Publications, 379.

Lehman, T.M. 1994a. The saga of the Dockum Group and the case of the Texas/New Mexico boundary fault. New Mexico Bureau Mines and Mineral Resources Bulletin, 150:37-51.

Lehman, T.M. 1994b. Save the Dockum Group! West Texas Geological Society Bulletin, 34:5-10.

Lehman, T.M. and Chatterjee, S. 2005. The depositional setting and vertebrate biostratigraphy of the Triassic Dockum Group of Texas. Indian Journal of Earth System Science, 114:325-351.

Lehman, T.M., Chatterjee, S., and Schnable, J.P. 1992. The Cooper Canyon Formation (Late Triassic) of western Texas. The Texas Journal of Science, 44:349-355.

Lucas, S.G. and Anderson, O.J. 1993a. Lithostratigraphy, sedimentation, and sequence stratigraphy of Upper Triassic Dockum Formation, West Texas, p. 55-65. In Crick, R.E. (ed.), 1993 Southwest Section Geological Convention, Transactions and Abstracts. American Association of Petroleum Geologists, Arlington.

Lucas, S.G. and Anderson, O.J. 1993b. Triassic stratigraphy in southeastern New Mexico and southwestern Texas, p. 231-235. In Love, D.W., Hawley, J.W., Kues, B.S., Adams, J.W., Austin, G.S., and Barker, J.M. (eds.), New Mexico Geological Society Field Conference Guidebook 44. New Mexico Geological Society, Albuquerque.

Lucas, S.G. and Anderson, O.J. 1995. Dockum (Upper Triassic) stratigraphy and nomenclature. West Texas Geological Society Bulletin, 34:5-11.

Lucas, S.G. and Hunt, A.P. 1989. Revised Triassic stratigraphy in the Tucumcari basin, east-central New Mexico, p. 150-169. In Lucas, S.G. and Hunt, A.P. (eds.) Dawn of the Age of Dinosaurs in the American Southwest. New Mexico Museum of Natural History, Albuquerque.

Lucas, S.G., Hunt, A.P., and Kahle, R. 1993. Late Triassic vertebrates from the Dockum Formation near Otis Chalk, Howard County Texas, p. 245-260. In Love, D.W., Hawley, J.W., Kues, B.S., Adams, J.W., Austin, G.S., and Barker, J.M. (eds.), New Mexico Geological Society Field Conference Guidebook 44. New Mexico Geological Society, Albuquerque.

Martz, J.W. 2008. Lithostratigraphy, chemostratigraphy, and vertebrate biostratigraphy of the Dockum Group
(Upper Triassic), of southern Garza County, West Texas. Unpublished Ph.D. thesis, Texas Tech University, Lubbock, Texas, USA.

Martz, J.W., Mueller, B.D., Nesbitt, S.J., Stocker, M.R., Parker, W.G., Atanassov, M., Fraser, N., Weinbaum, J., and Lehane, J.R. 2013. A taxonomic and biostratigraphic re-evaluation of the Post Quarry vertebrate assemblage from the Cooper Canyon Formation (Dockum Group, Upper Triassic) of southern Garza County, western Texas. Proceedings of the Royal Society of Edinburgh, 103:339-364.

Nesbitt, S.J. 2011. The early evolution of archosaurs: relationships and the origin of major clades. Bulletin of the American Museum of Natural History, 352:1292.

Nesbitt, S.J. and Chatterjee, S. 2008. Late Triassic dinosauriforms from the Post Quarry and surrounding areas, west Texas, USA. Neues Jahrbuch für Geologie und Paläontologie Abhandlungen, 249:143-156.

Nesbitt, S.J., Irmis, R.B., and Parker, W.G. 2007. A critical re-evaluation of the Late Triassic dinosaur taxa of North America. Journal of Systematic Palaeontology, 5:209-243.

Nesbitt, S.J., Irmis, R.B., Parker, W.G., Smith, N.D., Turner, A.H., and Rowe, T. 2009. Hindlimb osteology and distribution of basal dinosauromorphs from the Late Triassic of North America. Journal of Vertebrate Paleontology, 29:498-516.

Nesbitt, S.J., Sidor, C.A., Irmis, R.B., Angielczyk, K.D., Smith, R.M.H., and Tsuji, L.A. 2010. Ecologically distinct dinosaurian sister group shows early diversification of Ornithodira. Nature, 464:95-98.

Norman, D.B., Crompton, A.W., Butler, R.J., Porro, L.B., and Charig, A.J. 2011. The Lower Jurassic ornithischian dinosaurs Heterodontosaurus tucki Crompton and Charig, 1962; cranial anatomy, functional morphology, taxonomy, and relationships. Zoological Journal of the Linnean Society, 163:182-276.

Norman, D.B., Witmer, L.M., and Weishampel, D.B. 2004. Basal Ornithischia, p.325-334. In In Weishampel, D.B., Dodson, P. and Osmólska, H. (eds.), The Dinosauria, second edition. University of California Press, Berkeley.

Novas, F.E. 1992. Phylogenetic relationships of the basal dinosaurs, the Herrerasauridae. Palaeontology, 35:51-62.

Novas, F.E. 1993. New information on the systematics and postcranial skeleton of Herrerasaurus ischigualastensis (Theropoda: Herrerasauridae) from the Ischigualasto Formation (Upper Triassic) of Argentina. Journal of Vertebrate Paleontology, 13:400-423.

Parker, W.G. and Martz, J.W. 2011. The Late Triassic (Norian) Adamanian-Revueltian tetrapod faunal transition in the Chinle Formation of Petrified Forest National Park, Arizona. Earth and Environmental Science Transactions of the Royal Society of Edinburgh, 101:231-260. 
Peecook, B.R, Sidor, C.A., Nesbitt, S.J., Smith, R.M., Steyer, J.S., and Angielczyk, K.D. 2013. A new silesaurid from the Upper Ntawere Formation of Zambia (Middle Triassic) demonstrates the rapid diversification of Silesauridae (Avemetatarsalia, Dinosauriformes). Journal of Vertebrate Paleontology, 33:1127-1137.

Ramezani, J., Fastovsky, D.E., and Bowring, S.A. 2014. Revised chronostratigraphy of the lower Chinle Formation strata in Arizona and New Mexico (USA): High precision $\mathrm{U}-\mathrm{Pb}$ geochronological constraints on the Late Triassic evolution of dinosaurs. American Journal of Science, 314:981-1008.

Riggs, N.R., Lehman, T.M., Gehrels, G.E., and Dickinson, W.R. 1996. Detrital zircon link between headwaters and terminus of the Upper Triassic ChinleDockum Paleoriver system. Science, 273:97-100.

Romer, A.S. 1971. The Chañares (Argentina) Triassic reptile fauna $X$. Two but new incompletely known long-limbed pseudosuchians. Breviora, 378:1-10.

Romer, A.S. 1972. The Chañares (Argentina) Triassic reptile fauna. XV. Further remains of the thecodonts Lagerpeton and Lagosuchus. Breviora, 390:1-7.

Sarıgül, V. 2014. Anatomy of the Late Triassic Dinosauromorphs from the Dockum Group of Texas: Their Biostratigraphic, Paleobiogeographic and Evolutionary Significance. Unpublished Ph.D. thesis, Texas Tech University, Lubbock, Texas, USA.
Sereno, P.C. 1991. Lesothosaurus, "fabrosaurids," and the early evolution of Ornithischia. Journal of Vertebrate Paleontology, 11:168-197.

Sereno, P.C. and Arcucci, A.B. 1993. Dinosaurian precursors from the Middle Triassic of Argentina: Lagerpeton chanarensis. Journal of Vertebrate Paleontology, 13:385-399.

Sereno, P.C. and Arcucci, A.B. 1994. Dinosaurian precursors from the Middle Triassic of Argentina: Marasuchus lilloensis, gen. nov. Journal of Vertebrate Paleontology, 14:53-73.

Sereno, P.C., Martinez, R.N. and Alcober, O.A. 2013. Osteology of Eoraptor lunensis (Dinosauria, Sauropodomorpha). Journal of Vertebrate Paleontology, 32:83-179.

Small, B.J. 2009. A Late Triassic dinosauromorph assemblage from the Eagle Basin (Chinle Formation), Colorado, U.S.A. Journal of Vertebrate Paleontology, 29:182A.

Sullivan, R.M. and Lucas, S.G. 1999. Eucoelophysis baldwini, a new theropod dinosaur from the Upper Triassic of New Mexico, and the status of the original types of Coelophysis. Journal of Vertebrate Paleontology, 19:81-90.

Woody, D.T. 2006. Revised stratigraphy of the lower Chinle Formation (Upper Triassic) of Petrified Forest National Park, Arizona, p. 17-45. In Parker, W.G., Ash, S.R., and Irmis, R.B. (eds.), A Century of Research at Petrified Forest National Park, Museum of Northern Arizona Bulletin No. 62. 